\title{
Effect of Net House on Tomato Leaf Miner (Tuta absoluta) (Meyrick) (Lepidoptera: Gelechiidae) Population in Tomato Cultivated in Chitwan, Nepal
}

\author{
Ankit Soti ${ }^{1, a, *}$, Rajendra Regmi ${ }^{2, b}$, Arjun Kumar Shrestha ${ }^{2, c}$, Resham Bahadur Thapa ${ }^{3, d}$ \\ ${ }^{I}$ Agriculture and Forestry University, Chitwan, Nepal \\ ${ }^{2}$ Agriculture and Forestry University, Chitwan, Nepal \\ ${ }^{3}$ Institute of Agriculture and Animal Science, Tribhuwan University, Nepal \\ ${ }^{*}$ Corresponding author
}

A R T I C L E I N F O

Research Article

Received : $15 / 05 / 2020$

Accepted : 26/07/2020

\section{Keywords:}

Tuta absoluta

Net House

Open Condition

Yield

Investment

\section{A B S T R A C T}

This experiment was conducted in tomato field at Agriculture and Forestry University (AFU, Chitwan, Nepal) between October 2016 and May 2017 to evaluate effect of net house on invasive insect species of tomato moth, Tuta absoluta (Meyrick) (Lepidoptera: Gelechiidae). The trial was setup with two treatments inside net house and under open conditions and was designed with four replications. The adults of $T$. absoluta were observed significantly lower numbers inside the net house (1.41 adult/trap) compared to the open condition (24.84 adult/trap). The $T$. absoluta population increased with rainfall. The marketable yield was significantly higher inside the net house $(100.91 \mathrm{ton} / \mathrm{hec})$ due to reduction of damage to tomato fruit ( $4 \mathrm{ton} / \mathrm{hec})$ by $T$. absoluta. The initial level of investment was found to be higher inside the net house when compared to open cultivation. In terms of economic analysis in long term aspect only, the net house is a suitable means of pest management against $T$. absoluta. ankitsoti18@gmail.com akshrestha@afu.edu.np https://orcid.org/0000-0002-9253-2033

\section{b@ rregmi@afu.edu.np
d@ profrbthapa@gmail.com}

https://orcid.org/0000-0002-3882-1029 https://orcid.org/0000-0002-5303-4859

\section{Introduction}

Tomato (Lycopersicon esculentum Miller) is considered as one of the most widely grown vegetables all over the world and is the second most important vegetable crop after potato (Panthee and Chen, 2010). Tomato is the third most important vegetable after cauliflower and cabbage in terms of area and production in Nepal. It is cultivated in about 20,000 hectares (hec) with 0.3 millionton production value annually (MoAD, 2014). Insect pests play a major role for declining tomato yield. The crop loss due to pest is estimated to be $35-40 \%$ of the total production (PPD FAO, 2004). Tomato moth, Tuta absoluta (Meyrick) (Lepidoptera: Gelechiidae) is considered a typical invasive species because of its capacity to develop very quickly during tomato cultivation and to spread rapidly to new areas causing economically relevant damage (Desneux et al., 2010). In Nepal, invasion of $T$. absoluta was declared on $16^{\text {th }}$ of May, 2016 (Bajracharya et al., 2016).

The sex pheromone of T. absoluta is used for insect monitoring and mating disruption. Virgin female tomato leaf miner releases a sex pheromone that strongly attracts males. This pheromone was identified by Attygalle et al. (1996) as (3E, 8Z, 11Z)-3, 8, 11- etradecatrien-1-xyl acetate. Captures in traps baited with synthetic pheromone lures accurately show whether a specific insect species is present, and when its seasonal flight period starts (Witzgall et al., 2010).

In Nepal, the average pesticides use is $396 \mathrm{gm} \mathrm{a.i/ha}$ (PPD, 2015) and more than 85 percent of imported pesticides are applying only in vegetable crops in Nepal (Sharma, 2015). Massive use of chemical pesticides in vegetable growing areas raised possible health risks issue in Nepal (Atreya, 2007).

Pesticides used in tomato production to reduce the yield loss leads to occurrence of resistance in pest and diseases (Hossain et al., 2013). In this condition, the major challenge is to control insect pests by minimizing use of the chemical pesticides. Therefore, this study was aimed to evaluate the effectiveness of net house in management of T. absoluta and compare the yield of tomato in net house with other treatments. 


\section{Materials and Methods}

The experiment was conducted at horticultural research field of AFU, Chitwan. According to the geographical classification of country, it falls in the terai region of Central Development Region. Geographically it is located at $27^{\circ} 37^{\prime} \mathrm{N}$ latitude and at an altitude of 256 meter above sea level (Thapa and Dangol, 1990). Monthly average data on different weather parameters such as maximum and minimum temperatures, total rainfall and relative humidity was obtained from National Maize Research Program (NMRP, Rampur, Chitwan) during the tomato growing season. The experiment was laid out two treatments with four replications. The treatments were tomato cultivation inside net house and open condition. The net house size features were $5 \times 22 \mathrm{~m}^{2}$ area, $4 \mathrm{~m}$ height and 40 mess silver color net. Srijana tomato variety (NARC) was cultivated. Each plot size was $4.5 \mathrm{~m} \times 2.4 \mathrm{~m}\left(10.8 \mathrm{~m}^{2}\right)$ and consisted 24 tomato plants planted at a distance of $75 \mathrm{~cm}$ row to row and $60 \mathrm{~cm}$ plant to plant. Inner six plants were chosen randomly as a sample plant from each plot and tagged for data collection of insects and yield attributing characters.

Pheromone (TLM lure) was used for monitoring of $T$. absoluta. Pheromones were placed in ottaT-trap. Lures were replaced up in monthly intervals. In weekly basis the number of insects was counted in the trap. Data were collected for different parameters such as plant height, diameter, days of flowering and fruiting, marketable yield, unmarketable yield damaged by the $T$. absoluta, economic analysis as cost of cultivation, gross return, net profit and benefit cost ratio.

The collected data were compiled using the MS-Excel program. Analysis of variance for all parameters was carried out as per the procedures given in R-STATC statistical computer package for the paired two T- test.

\section{Results and Discussion}

\section{lure}

Monitoring of Tuta Absoluta Using Pheromone TLM

The adult of $T$. absoluta was observed first in pheromone trap outside the net house on $13^{\text {th }}$ February 2017. Significantly large number of insects was trapped onward till $3^{\text {rd }}$ April 2017. The average temperature recorded during the first emergence of $T$. absoluta in field was $18.7^{\circ} \mathrm{C}$ with maximum and minimum temperature of $27^{\circ} \mathrm{C}$ and $10.4^{\circ} \mathrm{C}$. The peak population was recorded at the $1^{\text {st }}$ week of April when the average temperature was $26.1^{\circ} \mathrm{C}$ with $\left(33.2^{\circ} \mathrm{C}\right.$ maximum temperature and $19^{\circ} \mathrm{C}$ minimum temperature) (Figure 1). The positive linear relationship between $T$. absoluta population and rainfall, where $\mathrm{R}$ square value was 0.70 and equation $\mathrm{y}=2.2888 \mathrm{x}-3.993$ shows that T. absoluta population incidence increased with the rainfall.

Tuta absoluta population inside the net house and open condition

T. absoluta adult population was observed to be significantly lower inside the net house (1.41) than open cultivation tomato (24.84) shown in Figure 2. There was significant difference among the treatments in terms of number of T. absoluta. The p-value was found to be 0.036 $(\mathrm{P}<0.05)$.

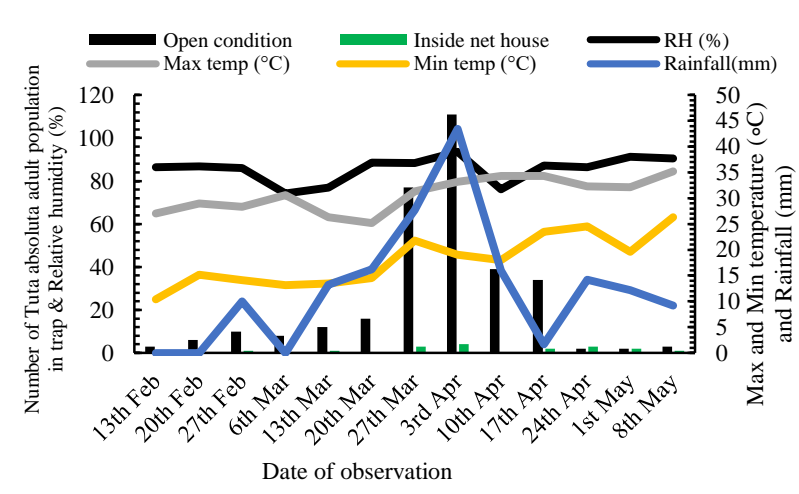

Figure 1. Graphical diagram showing number of Tuta absoluta adult population capture in trap in different dates of monitoring

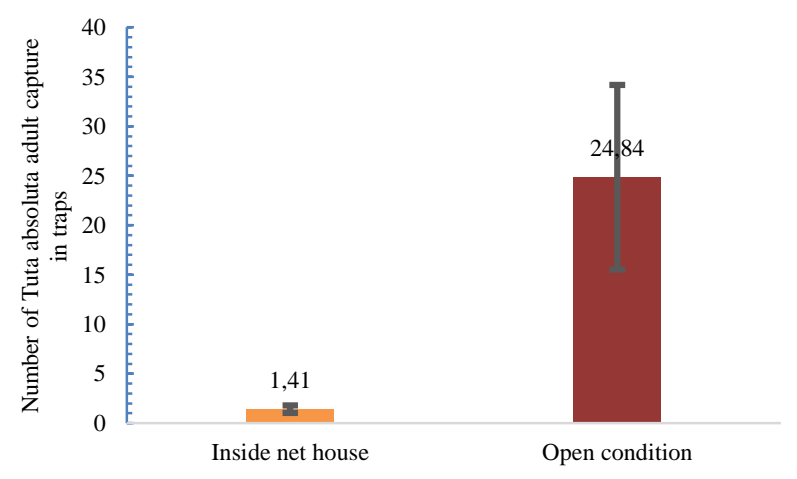

Figure 2. Number of Tuta absoluta population capture in traps in different treatments

\section{Yield Attributing Characters of Tomato Crops}

There was no significant difference in vegetative and flowering characteristics between the treatments, although variation was recorded in plant height, diameter of plant, days of $50 \%$ flowering, days of $50 \%$ fruiting (Table 1).

\section{Yield}

The result shows that there was significant difference between two treatments indicating that the yield was high in net house compared to open condition with p-value less than 0.05 . The reduction of insect pest infestation was the major reason behind the increase in yield. As shown in Figure 3, yield infested by $T$. absoluta was recorded maximum in the open condition with 13.79 ton/hec and was minimum inside net house 4 ton/hec. As shown in Figure 4 , the average yield of tomato in the net house is 100.91 ton/ha and 68.3 ton/ha in open condition. $47.73 \%$ of higher marketable yield was recorded inside the net house than open condition.

\section{Economic analysis}

While total cost of cultivation inside net house was $8963.34 \$ /$ hec, value for in open condition was 6059.70 $\$ /$ hec. The total average fruit yield was found in net house and open condition to be $100.81 \mathrm{ton} / \mathrm{hec}$ and $68.31 \mathrm{ton} / \mathrm{hec}$, respectively. Similarly, while average market price of tomato at the time of harvest was $250 \$ /$ ton inside net house and it was $200 \$ /$ ton in open condition. 
Table 1. Effect of different treatments on yield attributing characters of tomato crops

\begin{tabular}{l|cccccc}
\hline \multicolumn{1}{c|}{ Treatment } & $\begin{array}{c}\text { Plant height } \\
(\mathrm{cm})\end{array}$ & $\begin{array}{c}\text { Diameter of } \\
\text { plant }(\mathrm{cm})\end{array}$ & $\begin{array}{c}\text { First flowering } \\
(\text { days })\end{array}$ & $\begin{array}{c}50 \% \text { flowering } \\
(\text { days })\end{array}$ & $\begin{array}{c}\text { First fruiting } \\
(\text { days })\end{array}$ & $\begin{array}{c}50 \% \text { fruiting } \\
(\text { days })\end{array}$ \\
\hline Inside net house & $211.375 \pm 11.44$ & $16.61 \pm 0.55$ & $36 \pm 0.81$ & $42.75 \pm 0.25$ & $50.75 \pm 0.25$ & $57 \pm 0.4$ \\
Open condition & $187.375 \pm 6.62$ & $15.2 \pm 1.1$ & $34.5 \pm 1.04$ & $42 \pm 0.57$ & $50.25 \pm 1.37$ & $56.75 \pm 0.47$ \\
P-value & 0.1315 & 0.316 & 0.3024 & 0.2978 & 0.7432 & 0.7052 \\
\hline
\end{tabular}

Table 2. Economic analysis of tomato cultivation among different treatment

\begin{tabular}{l|cccccc}
\hline \multicolumn{1}{c|}{ Treatments } & $\begin{array}{c}\text { Total cost of } \\
\text { cultivation }(\$ / \mathrm{hec})\end{array}$ & $\begin{array}{c}\text { Total fruit yield } \\
(\text { ton } / \mathrm{hec})\end{array}$ & $\begin{array}{c}\text { Market price } \\
(\$ / \text { ton })\end{array}$ & $\begin{array}{c}\text { Gross income } \\
(\$ / \mathrm{hec})\end{array}$ & $\begin{array}{c}\text { Net profit } \\
(\$ / \mathrm{hec})\end{array}$ & $\begin{array}{c}\text { Benefit } \\
\text { cost ratio }\end{array}$ \\
\hline Net house & 8963.34 & 100.91 & 250 & 25229.67 & 16266.32 & $2.81: 1$ \\
Open condition & 6059.70 & 68.31 & 200 & 13662.47 & 7602.77 & $2.25: 1$ \\
\hline
\end{tabular}

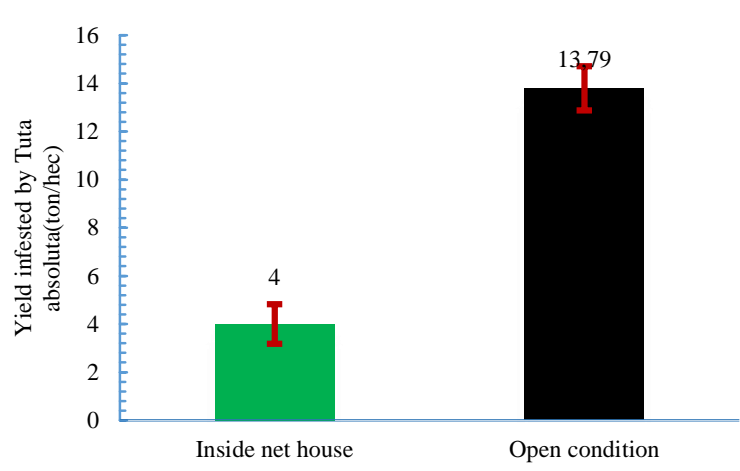

Figure 3. Yield infested by Tuta absoluta in different treatments

The net profit was exerted maximum inside the net house with black polythene mulch (16266.32\$) and lower in open condition (7602.77\$) as shown in Table 2. Assuming the life of net house for 10 years and 2 seasons of cropping inside net house, the economic analysis has been done.

\section{Discussion}

Development time decreased with increasing temperature ranging from 78.17 days to 21.39 days within the range of $15-29^{\circ} \mathrm{C}$. This range well encompasses the estimate of the optimum developmental threshold reported to be around the value of $25^{\circ} \mathrm{C}$ (Abolmaaty et al., 2011). The average development times are 76.3, 39.8 and 23.8 days at $14^{\circ} \mathrm{C}, 19.7^{\circ} \mathrm{C}$ and $27.1^{\circ} \mathrm{C}$, respectively (EPPO, 2005).

According to our results, net house is very much effective in controlling insect pest like T. absoluta. Net house restricts the adult T.absoluta to enter in field. Similar result was observed by Cherif et al. (2013) and use of insect-proof screens significantly prevented $T$. absoluta infestations on host plants.

As the duration of harvesting was found maximum and insect pest activity was minimum inside the net house was reason for the maximum yield inside net house. These finding seems to be compatible with Palada and Ali (2007). The net shade greatly reduced insect population by $80 \%$ and marketable yield was 1.5 to 2 times greater under than in the open field.

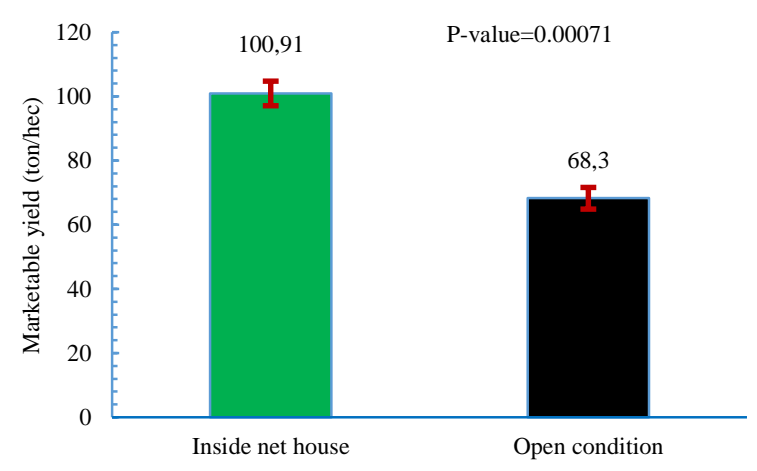

Figure 4. Marketable tomato yield in different treatments

\section{Conclusion}

T. absoluta is major invasive pest of tomato. In the spring season, tomato cultivation inside the net house plays the vital role for the T. absoluta management and exclusion comparative to open condition. The T. absoluta population was increased with rainfall. Marketable yield of tomato inside net house was higher than open condition with lower damaged fruit. Initial investment inside net house cultivation was higher than open cultivation. However, the net profit inside the net house was found to be higher than open condition. Therefore, net house in long run is the suitable means of protective cultivation to minimize the losses and enhancement of yield.

\section{Acknowledgement}

I am thankful to NARDF (National Agricultural Research and Development Fund) providing financial support to accomplish my study. I also would like to thank AIFA project Winrock International and National Maize Research Program, NMRP, Rampur, Chitwan for technical support and facilitating weather data in my study

\section{References}

Abolmaaty SM, Khalil AA, Amna MH. 2011. Using degree-day unit accumulation to predict potato tubeworm incidence under climate change conditions in Egypt. Nat. Sci., 9(4): $156-160$. 
Atreya K. 2007.Pesticide use in Nepal: Understanding health cost from short term exposure. South Asian Network for Development and Environmental Economics (SANDEE), Kathmandu, Nepal. SANDEE Working paper No. 28-07.26 p. https://opendocs.ids.ac.uk/opendocs/handle/20.500.12413/4366

Attygalle AB, Jham GN, Svatoš A, Frighetto RT, Ferrara FA, Vilela EF, Meinwald J. 1996. (3E, 8Z, 11Z)-3, 8, 11Tetradecatrienyl acetate, major sex pheromone component of the tomato pest Scrobipalpuloides absoluta (Lepidoptera: Gelechiidae). Bioorganic \& Medicinal Chemistry, 4(3): 305314.

Bajracharya ASR, Mainali RP, Bhat B, Bista S, Shashank PR, Meshram NM. 2016. The first record of South American tomato leaf miner, Tuta absoluta (Meyrick 1917) (Lepidoptera: Gelechiidae) in Nepal. J. Entomol. Zool. Stud., 4: 1359-1363.

Cherif A, Mansour R, Grissa-Lebdi K. 2013. Biological aspects of tomato leaf miner Tuta absoluta (Lepidoptera: Gelechiidae) in conditions of northeastern Tunisia: Possible implications for pest management.Environmental and Experimental Biology, 11: 179-184.

Desneux N, Wajnberg E, Wyckhuys KA, Burgio G, Arpaia S, Narváez-Vasquez CA, Pizzol J. 2010. Biological invasion of European tomato crops by Tuta absoluta: ecology, geographic expansion and prospects for biological control. Journal of Pest Science, 83(3): 197-215.

EPPO 2005. Data sheets on quarantine pests Tuta absoluta. EPPO Bulletin, 35. https://onlinelibrary.wiley.com/toc/13652338/35/3

Hossain MS, Hossain MA, Rahman MA, Islam MM, Rahman MA, Adyel TM. 2013. Health risk assessment of pesticide residues via dietary intake of market vegetables from Dhaka, Bangladesh. Foods, 2(1): 64-75.
MoAD. 2014. Statistical information on Nepalese agriculture (2013/14). Government of Nepal, Ministry of Agricultural Development (MoAD), Agri-Business Promotion and Statistics Division, Statistics Section, Singha Durbar, Kathmandu, Nepal. https://www.academia.edu/28265859/ STATISTICAL_INFORMATION_ON_NEPALESE_AGRI CULTURE_AgriBusinessPromotionandStatisticsDivision_ AgristatisticsSection

Palada MC, Ali M. 2007. Evaluation of technologies for improving year-round. production of safe vegetables in periurban agriculture of Southeast Asia. Acta Horticulturae, 762: 271-281.

Panthee D, Chen F. 2010. Genomics of Fungal Disease Resistance in Tomato. Current Genomics, 11(1): 30-39.

PPD, FAO. 2004. Proceedings of officer level of training of facilitators in vegetable IPM, 13 June-25 September 2004, Hariharbhawan, Lalitpur, Nepal, pp. 1-79.

PPD. 2015. Annual Progress Report. Plant Protection Directorate, Hariharbhawan, Lalitpur, Nepal.

Sharma DR, 2015. Use of pesticides and its residue on vegetable crops in Nepal. Journal of Agriculture and Environment, 16: 33-42.

Thapa RB, Dangol BR. 1990. A preliminary survey of bee flora at IAAS and its vicinity. IAAS Research, Report 1985-1991, pp. 59-65.

Witzgall P, Kirsch P, Cork, A. 2010. Sex pheromones and their impact on pest management. Journal of Chemical Ecology, 36(1): 80-100. 